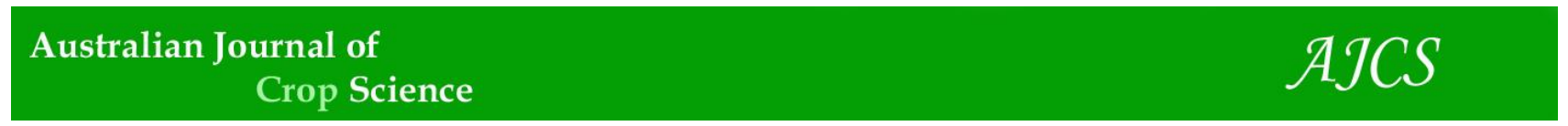

AJCS 14(12):1949-1956 (2020)

ISSN:1835-2707

doi: 10.21475/ajcs.20.14.12.2822

\title{
Edaphic invertebrate macrofauna associated with cassava crop in different soil
} coverages

\author{
Nathalia de França Guimarães ${ }^{1 *}$, Auro Akio Otsubo ${ }^{2}$, Rodrigo Arroyo Garcia ${ }^{2}$, Anderson de Souza Gallo ${ }^{1}$, \\ Emerson Machado de Carvalho ${ }^{3}$, Rogério Ferreira da Silva ${ }^{4}$
}

${ }^{1}$ Federal Rural University of Rio de Janeiro, Institute of agronomy, Soil Department, Seropédica, RJ, Brazil

${ }^{2}$ Embrapa Western Agriculture, Dourados, MS, Brazil

${ }^{3}$ Federal University of Southern Bahia, campus "Jorge Amado", Itabuna, BA, Brazil

${ }^{4}$ State University of Mato Grosso do Sul, Unity of Glória de Dourados, Glória de Dourados, MS, Brazil

\section{*Corresponding author: n.fguimaraes@hotmail.com}

\section{Abstract}

This study aimed to identify and assess the edaphic invertebrate macrofauna associated with cassava crop in succession to different soil coverages. The experimental design was randomized blocks as $6 \times 3$ factorial design with four replications. The first factor was soil cover cultivated from December 2014 to April 2015 (fallow, pearl millet, forage sorghum, Crotalaria ochroleuca, Urochloa ruziziensis and Corn+Urochloa ruziziensis). The second factor was sampling periods (March/2015, October/2015 and June/2016). We sampled four blocks of $0.25 \times 0.25 \times 0.20 \mathrm{~m}$ in each system, following the TSBF (Tropical Soil Biology and Fertility) collection method. The taxonomic composition and abundance of organisms, richness of groups and the diversity indexes of Shannon, Pielou equitability and Simpson dominance were evaluated. There was no interaction between the factors (soil cover $\mathrm{x}$ season) for the variables studied. There was difference in the dominance of organisms according to the soil cover (isolated), being the highest index (0.44) obtained by previous cultivation of forage sorghum. The abundance of organisms, group richness and diversity index were influenced by sampling period, demonstrating the influence of seasonality on the invertebrate macrofauna community of the soil.

Keywords: Soil organisms, cover crops, Manihot esculenta Crantz, soil quality, no-till farming.

\section{Introduction}

Brazil is one of the world leaders in cassava production. According to the Brazilian Institute of Geography and Statistics (IBGE, 2017), Brazilian production of this root will reach over 20 million tons in 2017, being Mato Grosso do Sul one of the largest producers. This is due to the fact that in this region, the edaphoclimatic characteristics are favorable to the production (Silva et al., 2008). In addition, the country is a pioneer in soil conservation with the no-tillage system, a practice that has been keeping agricultural productivity high for several crops (Devide et al., 2017), including cassava leading to increase of root production and starch content (Amabile et al., 1994; Oliveira et al., 2001).

The use of cover plants, combined with the no-tillage system promotes several benefits to the soil system, as these plants contribute to nutrient cycling, water storage and increase in organic matter (Santos et al., 2008). They also maintain a lower soil temperature in the top layer. The cover plants also improve several parameters related to the physical attributes of the soil (Silva et al., 2008), such as the structure and resistance to penetration through "biopores" derived from decomposition of aggressive root system of previous crops.
From the point of view of biological attributes, several studies indicate that the use of cover crops causes numerous changes in soil quality (Cordeiro et al., 2004; Silva et al., 2007; Crotty et al., 2015; Dudás et al., 2016). According to Baretta et al., (2003), the soil fauna can be benefited by the increase in the quality and quantity of vegetal residues, changing its composition and diversity in different degrees of intensity through changes in habitat, food supply, creation of microenvironments and intraspecific and interspecific competition (Marques et al., 2014; Terry et al., 2015).

The soil invertebrate macrofauna is composed of animals with a body diameter between $2 \mathrm{~mm}$ to $20 \mathrm{~mm}$ and they can belong to almost all orders (Lavelle and Spain, 2001; Correia and Oliveira, 2005). These organisms play a key role in the functioning of the ecosystem, as they occupy several trophic levels within the soil food chain (Silva et al., 2007). They can influence soil processes through two main pathways: directly, through the physical modification of the litterfall and the soil environment, and indirectly, through interactions with the microbial community (González et al., 2001). They regulate populations through selective predation of fungi and bacteria, stimulation, digestion and dissemination of ingested microorganisms and the 
fragmentation of debris (Brown, 1995; Cragg and Bardgett, 2001). Besides, they are used as indicators of soil quality as they are sensitive and react quickly to changes induced by anthropogenic activities and environmental disturbances (Rousseau et al., 2012; Guimarães et al., 2016).

Thus, this work aims to evaluate the edaphic invertebrate macrofauna associated with cassava culture in succession to different soil coverings.

\section{Results and Discussion}

\section{Dry mass of cover plants}

There was a difference in aerial part of dry mass (APDM) of the cover plants. The dry mass of the sorghum treatment was higher than the degraded meadow cover (M), millet, crotalaria and intercropped corn, not only differing from the single brachiaria (Figure 1). This result corroborates with Carvalho et al. (2013), who identified sorghum having highest production of green and dry matter with high production of phytomass for soil protection.

All treatments accumulated dry mass above $6 \mathrm{t} \mathrm{ha}^{-1}$ (Figure 1). According to Alvarenga et al. (2001), this amount of APDM on the surface is sufficient to obtain good soil coverage, ensuring the beneficial effects regarding the maintenance and/or improvement of the soil's biological characteristics. According to Cordeiro et al. (2004), the good amount of vegetal residues on the soil can promote new habitats and food availability, changing the diversity of the edaphic fauna community.

\section{Relative frequency of the soil macrofauna organisms}

The composition of the soil macrofauna community in three sampling periods showed that collected organisms belonged to the following six taxonomic groups: Oligochaeta (Annelida), Isoptera, Heteroptera, Coleoptera and Formicidae (Arthropoda: Insecta) and others (Table 2).

In the first evaluation (March/2015) of the systems under cover (treatments) of millet, sorghum and corn + Urochloa revealed a higher presence of the Oligochaeta, with $79 \%$, $42 \%$ and $58 \%$ of the individuals collected, respectively. The Formicidae group showed low predominance in all treatments, as it reached $10 \%$ of the total macrofauna individuals in no soil cover.

The Isoptera group was the one with the highest profile in the $1^{\text {st }}$ sampling. In crotalaria and Urochloa treatments, the group represented $87 \%$ and $68 \%$ of the quantified individuals, respectively. In addition, it was the second most prevalent in fallow and Corn + Urochloa. This result may be associated with the fact that the experiment was implemented over an occupied area with pasture in the process of degradation. In fact, isoptera is an order formed by individuals known as termites. According to Aquino et al. (2008), the high presence of these organisms can be a sign of the degradation process in pastures, where they occur in high numbers. According to Cunha and Morais (2010), the formation of pastures facilitates the proliferation of termite mounds because of the homogeneity of the environment and the absence of competitors.

In October 2015 ( $2^{\text {nd }}$ sampling), there was a sharp decline in the presence of organisms in the Isoptera group, with a predominance in Crotalaria only (Table 2). In the sorghum and corn + Urochloa systems, the group was not even captured. This occurrence may be related to the management of cover crops, showing improvement in soil quality over time. The straw accumulated by the plants provided a favorable environment for the communities of the edaphic macrofauna (Silva et al., 2007), mainly for providing food and shelter to the weather. Therefore, it seems to have conditions for the establishment of the other groups of macrofauna.

We found a dominance of Heteroptera and Formicidae in fallow, which altogether accounted $75 \%$ of the total individuals of the invertebrate macrofauna. The Heteroptera group was also the most present in millet $150 \%$ of individuals), followed by Isoptera and Coleoptera, with $33 \%$ and $16 \%$, respectively. In Sorghum, the Coleoptera group was prevailed, accounting for $80 \%$ of the total of organisms. The Formicidae group stood out in the Urochloa and Maize + Urochloa systems, representing $68 \%$ and $89 \%$ of individuals, respectively.

In the third sampling period, the Formicidae group was more frequent in five of the soil cover systems (treatments), except for the millet, in which Isoptera predominated (64\%) (Table 2). The behavior of the Formicidae group is highlighted, which in the first evaluation had low frequency, increasing its population over time, except in corn + Urochloa cv. ruziziensis. This result can be attributed to the improvement of soil properties due to cover crops (Silva et al., 2007). The high presence of individuals in this group is commonly associated with changes in soil management, especially during its reconditioning (Anderson et al., 2002). In addition, June was the driest $(25 \mathrm{~mm}$ ) among the seasons evaluated (Table 1). According to Santos et al. (2012), the frequency of ants is higher, when there is a reduction in precipitation and an increase in air temperature.

\section{Functional groups}

The groups of macroinvertebrates were classified into five functional groups: saprophagous-Oligochaeta and Blattodea; predator-Chilopoda, Araneae, Dermaptera and Hymenoptera (excluding Formicidae); saprophage-predator Isoptera, Coleoptera and Formicidae; phytophagousOrthoptera and Heteroptera; and others: Diptera (Figure 2). In the first season, saprophages and saprophage-predators were the most significantly groups present in most soil coverings, except in fallow (spontaneous vegetation), which had the highest density of phytophages (48\%) (Fig 2A). Saprophages were more representative in the Millet, Corn + Urochloa and Sorghum systems, with $74 \%, 58 \%$ and $42 \%$, respectively, a result attributed to the large number of individuals of the Oligochaeta class captured in these systems (Table 2). The saprophagous-predator group was the most representative in Crotalaria and Urochloa, with $93 \%$ and $70 \%$ of the organism density. Abundant populations of organisms in this group indicate a normal flow of energy within communities (Neutel et al. 2002), which is the normal functioning of the soil (Rousseau et al., 2012). Sorghum showed a more uniform distribution of macrofauna individuals due to functional groups.

In the second season, in sorghum (93.3\%), crotalaria (100\%) Urochloa $(77.3 \%)$ and corn + Urochloa (96\%) coverings, there was a greater expression of saprophagous-predator macroinvertebrates (Figure 2B). These coverings 
accumulated the highest dry matter (Figure 1), suggesting that the abundance of individuals in this group responds to the increase in plant biomass in the soil (Sayer et al. 2010; Rousseau et al. 2012). In crotalaria, $100 \%$ of organisms belong to this group, suggesting a food preference for the plants of this family, which may be related to their low $\mathrm{C} / \mathrm{N}$ ratio (Silva et al., 2007). At fallow, saprophage-predators showed similar behavior to phytophages, with $50 \%$ of the organisms for each group. Spontaneous vegetation environments can be important sources of shelter and food for soil predators and their presence contributes to the control of phytophagous populations (Marasas et al., 2010). In the third sampling period, the saprophage-predators showed high representativeness in all soil coverings (Figure $3 C)$, a result related to the high dominance of the groups Formicidae, Isoptera and Coleoptera (Table 2), all of them saprophages-predators. Therefore, it is possible to affirm that the plant material of cover plants favors individuals in this functional group in a more advanced degree of decomposition over time, who feed on dead organic matter. At the same time, they regulate populations of organisms from other groups, as they also play a role as predators in agroecosystems, explaining the group's high dominance in all soil coverings tested in the third sampling.

\section{Abundance, richness of groups and ecological indexes}

There was no significant interaction $(p>0.05)$ between the two studied factors (soil cover $x$ season) for the variables abundance of organisms (AO), richness of groups (RG), diversity indices (DI), equitability (E) and dominance (Do) (Table 3).

When analyzing the levels apart, we found that only the 'Do' showed a significant difference $(p<0.01)$ due to the soil cover. Sorghum showed the highest value to 'Do' compared to fallow and Millet, without statistically differing from the other ground covers (Crotalaria, Urochloa and Corn + Urochloa) (Table 3). Simpson's index was expressed whether there is dominance by one or a few species and varies from 0 to 1 , the closer to 1 the greater the dominance of a given group. Therefore, the highest Simpson's index is related to the dominance of some groups in this system, mainly Oligochaeta, which was one of the most expressive in March (first sampling season). The Coleoptera was most representative in October (second season sampling), reaching $80 \%$ of the composition of edaphic macroinvertebrates and Formicidae, which was one of the most dominant in June (third sampling season) (Table 2). This is due to the fact that sorghum was the covering with the highest accumulation of dry matter (Figure 1). The occurrence of a certain group of edaphic fauna is mainly due to the beneficial effects of vegetable residues kept on the soil surface, providing a more favorable environment for the survival of certain groups (Moço et al., 2005), as it provides food, humidity, favorable temperature, and protection from the weather (Guimarães et al., 2016).

Analysis of sampling times showed significant differences ( $p$ $<0.01$ ) for the variables AO, WG and DI (Table 3). For three variables, the first and third seasons (March/2015 and June/2016) were statistically superior to the second sample. This result demonstrates the influence of seasonality in the structure of the edaphic community, where differences found between the months, times or periods analyzed mainly associated with precipitation (Machado et al., 2015) and temperature, which can influence the pattern of distribution and diversity of many groups (Almeida et al., 2015).

Several authors reported edaphic invertebrates with greater abundance of organisms, richness of groups and diversity index in periods of greater precipitation (Moço et al., 2005; Silva et al., 2007; Almeida et al., 2015; Guimarães et al., 2016). This factor allied to biotic factors of the environment such as vegetation cover, which can contribute to the formation of different microsites (Moço et al., 2005; Almeida et al., 2015), favoring the establishment of several groups of soil invertebrate macrofauna.

In the present study, despite low rainfall in the sampling times of March (96 mm) and June $(25 \mathrm{~mm}$ ) (Table 1), the months leading up to these showed high rainfall (February and May), with $264 \mathrm{~mm}$ and $228 \mathrm{~mm}$, respectively. This occurrence may have influenced the highest values for abundance of organisms, group richness and Shannon's diversity index (Table 3), making the capacity of the vegetation cover of the studied plants to maintain soil moisture more evident (Santos et al., 2008).

\section{Cluster analysis}

The cluster analysis is a technique whose objective is to group management systems based on common characteristics (Guimarães et al., 2016). The cluster analysis showed the formation of two large distinct groups in relation to the edaphic macroinvertebrate community (Figure 3). These two groups did not show any similarity to each other, since their connection distance was $100 \%$.

The first group includes the fallow, Crotalaria and Urochloa systems with $70 \%$ similarity. This grouping was probably occurred due to the similarity between the three systems in terms of the abundance of macrofauna organisms (Table 2), since they were the most abundant. Within group 1 , the formation of two levels is perceived (Figure 3). Considering the levels, there was $34 \%$ dissimilarity between the Urochloa treatment and those of the fallow and Crotalaria systems. The formation of the level with the Fallow and Crotalaria is possibly associated with the similarity in the average values for the variables abundance of organisms and equitability index (Table 2).

The second group comprised of Millet, Sorgo and Corn + Urochloa systems, which showed a similarity of 54\%. Within this group, the formation of two independent and distant levels was observed. On one level, Corn + Urochloa were isolated with a $46 \%$ difference from Millet and Sorghum. This isolation probably was occurred due to the reduction in the abundance of macrofauna organisms in the system, being the only one that presented less than $200 \mathrm{~m}^{-2}$ organisms (Table 2). However, the Millet and Sorghum systems formed a second level, with $78 \%$ similarity between them, corroborating Silva et al. (2007), who evaluated effect of cassava cultivation in different soil cover systems on the density and diversity of the macrofauna community. They found similarity between sorghum and millet reaching up to $98 \%$. This result allows us to infer that these two grasses have a similar effect on the soil invertebrate macrofauna. 
Table 1. Precipitation (P), temperature (T) and relative humidity (RH) during the months of the experiment, Naviraí, MS, 2017. Source: Cooperativa Agrícola Sulmatogrossense (Copasul).

\begin{tabular}{|c|c|c|c|c|c|c|}
\hline \multirow{2}{*}{ Months } & \multicolumn{2}{|c|}{$\mathrm{P}(\mathrm{mm})$} & \multicolumn{2}{|l|}{$\mathrm{T}(\stackrel{\mathrm{o}}{ } \mathrm{C})$} & \multicolumn{2}{|c|}{ RH (\%) } \\
\hline & Total & $\mathrm{DA}^{6}$ & Max. & Min. & Max. & Min. \\
\hline $\mathrm{Dec} / 2014^{1}$ & 208 & 6.9 & 33.4 & 22.3 & 84.5 & 42.9 \\
\hline Jan/2015 & 138.0 & 4.4 & 35.2 & 22.8 & 83.8 & 39.9 \\
\hline Feb/2015 & 264.0 & 9.4 & 33.8 & 22.0 & 85.2 & 58.6 \\
\hline $\mathrm{Mar} / 2015^{2}$ & 96.0 & 3.0 & 33.7 & 21.3 & 85.1 & 49.3 \\
\hline Apr/2015 & 279.7 & 9.3 & 31.4 & 20.1 & 86.6 & 50.9 \\
\hline May $/ 2015^{3}$ & 259.0 & 8.3 & 27.0 & 16.9 & 86.3 & 60.5 \\
\hline Jun/2015 & 56.5 & 1.8 & 27.6 & 16.2 & 83.4 & 53.4 \\
\hline Jul/2015 & 290.4 & 9.3 & 28.4 & 15.3 & 84.6 & 67.7 \\
\hline Aug/2015 & 43.0 & 1.3 & 32.6 & 18.5 & 75.8 & 45.5 \\
\hline Sep/2015 & 342.0 & 11.4 & 31.6 & 19.5 & 79.2 & 50.2 \\
\hline Oct $/ 2015^{4}$ & 216.5 & 6.9 & 32.0 & 22.8 & 83.7 & 51.9 \\
\hline Apr/2016 & 95.0 & 3.1 & 33.8 & 21.3 & 77.4 & 43.9 \\
\hline May/2016 & 228.5 & 7.3 & 24.7 & 15.6 & 83.1 & 69.4 \\
\hline Jun/2016 ${ }^{5}$ & 25.0 & 0.8 & 24.3 & 12.6 & 88.7 & 80.9 \\
\hline
\end{tabular}

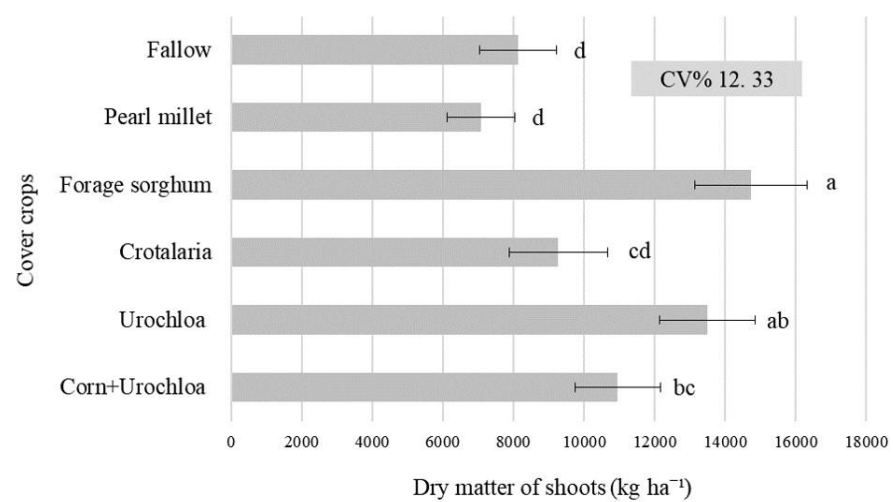

Fig 1. Dry mass of cover plants ( $\mathrm{kg} \mathrm{ha}^{-1}$ ) and standard deviation, Naviraí, MS, 2017. Fallow (F); Millet (Mi); Forage Sorghum (FS); Crotalaria ochroleuca (CR); Urochloa cv. Ruziziensis and corn + Urochloa cv. ruziziensis (C + UR). CV\% = Coefficient of variation.

Table 2. Relative frequency (\%) of soil macrofauna organisms in different soil coverings and fallow, in three evaluation periods. Naviraí, MS, 2017.

\begin{tabular}{|c|c|c|c|c|c|c|}
\hline \multirow{2}{*}{ Treat. * } & Formicidae & Isoptera & Coleoptera & Oligochaeta & Heteroptera & Others** \\
\hline & \multicolumn{6}{|l|}{$\%$} \\
\hline & \multicolumn{6}{|c|}{ March/2015 } \\
\hline $\mathrm{F}$ & 6 & 26 & 2 & 15 & 48 & 3 \\
\hline $\mathrm{Ml}$ & 4 & 6 & 5 & 79 & 2 & 4 \\
\hline FS & 6 & 3 & 8 & 42 & 25 & 16 \\
\hline $\mathrm{CR}$ & 2 & 87 & 4 & 2 & 5 & 0 \\
\hline UR & 3 & 68 & 1 & 2 & 26 & 0 \\
\hline \multirow[t]{2}{*}{$\mathrm{C}+\mathrm{UR}$} & 3 & 14 & 11 & 58 & 11 & 3 \\
\hline & \multicolumn{6}{|c|}{ October/2015 } \\
\hline $\mathrm{F}$ & 25 & 12.5 & 12.5 & 0 & 50 & 0 \\
\hline $\mathrm{Ml}$ & 0 & 33.3 & 16.7 & 0 & 50 & 0 \\
\hline FS & 13.3 & 0 & 80 & 0 & 0 & 6.7 \\
\hline $\mathrm{CR}$ & 0 & 75 & 25 & 0 & 0 & 0 \\
\hline UR & 68.2 & 6.9 & 9.1 & 11.3 & 0 & 4.5 \\
\hline \multirow[t]{2}{*}{$C+U R$} & 89.7 & 0 & 0 & 0 & 0 & 10.3 \\
\hline & \multicolumn{6}{|c|}{ June/2016 } \\
\hline $\mathrm{F}$ & 64 & 4 & 23 & 1 & 1 & 7 \\
\hline MI & 21 & 64 & 6 & 2 & 4 & 3 \\
\hline FS & 46 & 30 & 20 & - & 2 & 2 \\
\hline $\mathrm{CR}$ & 67 & 6 & 12 & - & 6 & 9 \\
\hline UR & 75 & 19 & 5 & - & - & 1 \\
\hline$C+U R$ & 45 & 28 & 15 & - & 9 & 3 \\
\hline
\end{tabular}

Hreat - Treatsentsieuca 
A
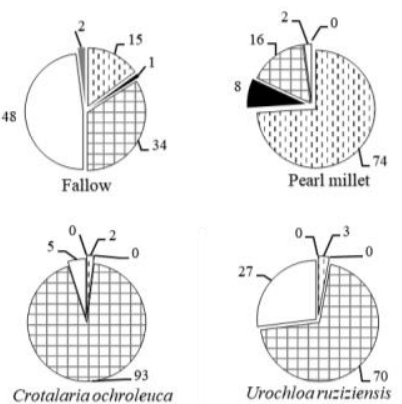

B
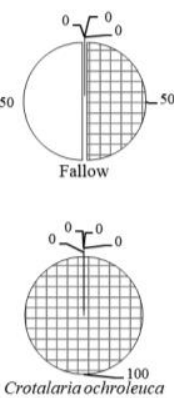

$\mathrm{C}$
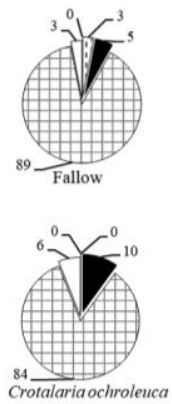

Pearl millet

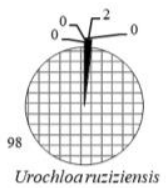

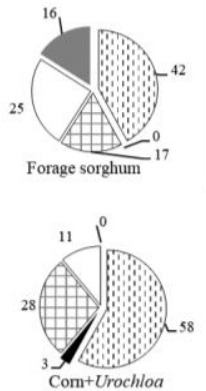
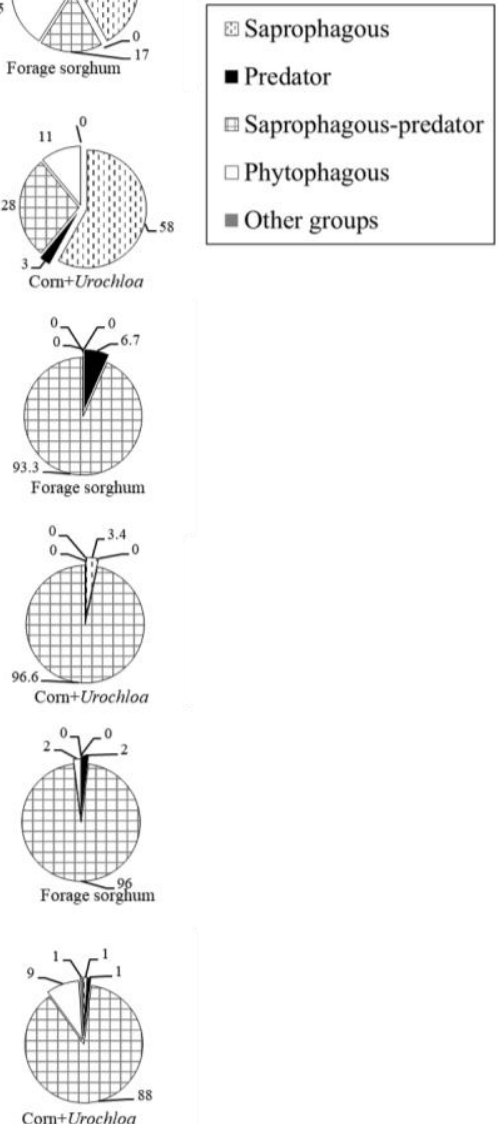

Fig 2. Relative density (\%) of the functional groups of the soil macrofauna organisms in different soil coverings and fallow, in the first (A), second (B) and third (C) evaluation period. Naviraí, MS, 2017. Saprophages (Oligochaeta and Blattodea); predator [Chilopoda, Araneae, Dermaptera and Hymenoptera (excluding Formicidae)]; Saprophages-predator (Isoptera, Coleoptera and Formicidae); phytophagous (Orthoptera and Heteroptera) and another (Diptera).

Table 3. Abundance of organisms - number of individuals $\mathrm{m}^{-2}(\mathrm{AO})$, Wealth of groups - number of groups (WG), Shannon diversity index (DI), Pielou equitability index (EI), Simpson's dominance index (Do) in different soil coverings and fallow, in three evaluation periods/seasons. Naviraí, MS, 2017.

\begin{tabular}{|c|c|c|c|c|c|}
\hline & $\mathrm{AO}^{1}$ & WG & $\mathrm{DI}$ & $\mathrm{EI}$ & $\mathrm{Do}^{2}$ \\
\hline & $\begin{array}{l}\text { Number of } \\
\text { individuals } \mathrm{m}^{-2}\end{array}$ & $\begin{array}{l}\text { Number of } \\
\text { groups }\end{array}$ & -----------. & --------- & \\
\hline \multicolumn{6}{|l|}{ Sistems } \\
\hline $\mathrm{F}$ & $426.41 \mathrm{a}$ & $3.58 \mathrm{a}$ & $0.39 a$ & $0.76 \mathrm{a}$ & $0.06 b^{* *}$ \\
\hline MI & $352.00 \mathrm{a}$ & $3.16 \mathrm{a}$ & $0.33 a$ & $0.72 \mathrm{a}$ & $0.11 \mathrm{~b}$ \\
\hline FS & 277.75 a & $2.66 \mathrm{a}$ & $0.29 a$ & $0.69 a$ & $0.44 \mathrm{a}$ \\
\hline$C R$ & $460.33 \mathrm{a}$ & $2.75 \mathrm{a}$ & $0.29 a$ & $0.74 \mathrm{a}$ & $0.20 a b$ \\
\hline UR & 531.44 a & $2.66 \mathrm{a}$ & $0.27 a$ & $0.71 \mathrm{a}$ & $0.26 a b$ \\
\hline $\mathrm{C}+\mathrm{UR}$ & $198.41 \mathrm{a}$ & $2.91 \mathrm{a}$ & $0.35 \mathrm{a}$ & $0.67 \mathrm{a}$ & $0.35 \mathrm{ab}$ \\
\hline \multicolumn{6}{|l|}{ Seasons } \\
\hline Mar./2015 & $501.87 a^{* *}$ & $3.20 a^{* *}$ & $0.35 a * *$ & $0.73 a$ & $0.30 \mathrm{a}$ \\
\hline Oct./2015 & $77.80 \mathrm{~b}$ & $2.00 \mathrm{~b}$ & $0.23 \mathrm{~b}$ & $0.67 a$ & $0.16 a$ \\
\hline Jun./2016 & $543.50 \mathrm{a}$ & $3.66 \mathrm{a}$ & $0.38 \mathrm{a}$ & $0.74 \mathrm{a}$ & $0.25 \mathrm{a}$ \\
\hline Interaction & & & Test $\mathrm{F}$ & & \\
\hline Sist $x$ Season & $1.74^{\mathrm{ns}}$ & $0.58^{\mathrm{ns}}$ & $0.74^{\mathrm{ns}}$ & $1.97^{\mathrm{ns}}$ & $0.72^{\mathrm{ns}}$ \\
\hline CV\% & 15.20 & 33.52 & 35.59 & 34.61 & 58.38 \\
\hline
\end{tabular}

Average with the same letters in the columns do not differ according to the Tukey's test. Fallow (F); Millet (MI); Forage sorghum (FS); Crotalaria ochroleuca (CR); Urochloa cv. ruziziensis; Corn + Urochloa $c v$. ruziziensis $(\mathrm{M}+\mathrm{UR}) .{ }^{* *}$ significant at the $1 \%$ probability level $(\mathrm{p}<0.01) .{ }^{\text {ns }}$ not significant $(\mathrm{p}>=0.05) .{ }^{1}$ Data transformed using the expression $\mathrm{x}=\log (\mathrm{x}) .{ }^{2}$ Data transformed using the expression $\mathrm{x}=\mathrm{v} \mathrm{x}$. System $\mathrm{x}$ Seasons - Systems $\mathrm{x}$ Seasons. 


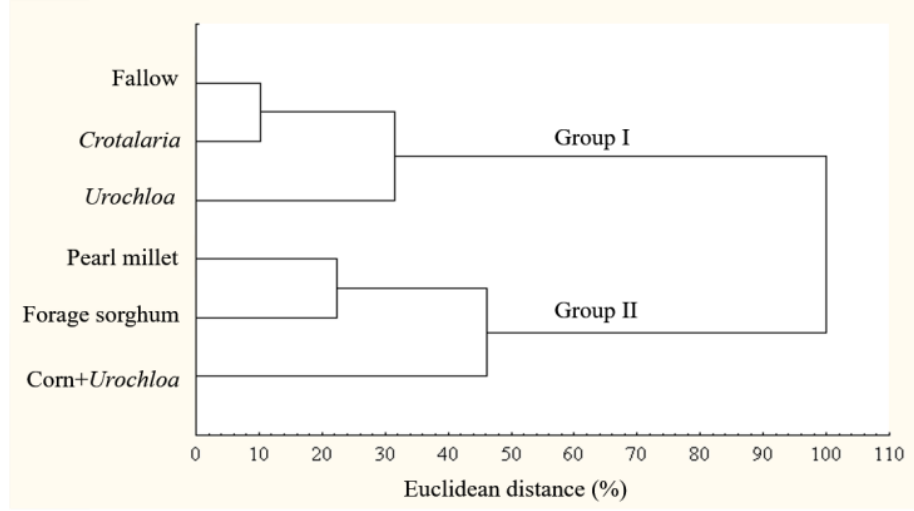

Fig 3. Dendrogram of dissimilarity of the edaphic macroinvertebrate community, based on Euclidean distance, under different ground cover and fallow (average of the three assessment periods), Naviraí, MS, 2017. fallow; millet; forage sorghum; Crotalaria ochroleuca; Urochloa cv. ruziziensis; corn + Urochloa cv. ruziziensis.

\section{Materials and Methods}

\section{Site location and characterization}

The experiment was implemented in the municipality of Naviraí, state of MS (2303'5411'; altitude of $364 \mathrm{~m}$ ), in the experimental area of Cooperativa Agrícola Sulmatogrossense (Copasul), on an area occupied with pasture in the process of degradation. The soil is classified as medium-textured dystrophic red latosol, whose chemical characteristics in the 0.0-0.20 m layer were: $\mathrm{pH}$ (in $\mathrm{CaCl}_{2}$ ) $=4.9 ; \mathrm{P}=4 \mathrm{mg} \mathrm{dm}^{-3}$; $\mathrm{K}=0.11 \mathrm{cmol}_{\mathrm{c}} \mathrm{dm}^{-3} ; \mathrm{Ca}=0.16 \mathrm{cmol}_{\mathrm{c}} \mathrm{dm}^{-3} ; \mathrm{Mg}=0.6 \mathrm{cmol}_{\mathrm{c}} \mathrm{dm}^{-}$ ${ }^{3} ; \mathrm{H}+\mathrm{Al}: 2.6 \mathrm{cmol}_{\mathrm{c}} \mathrm{dm}^{-3}$ and, soil organic matter $=21 \mathrm{~g} \mathrm{~kg}^{-1}$. According to Köppen and Geiger (1928), the region's climate is classified as Am (humid or sub-humid tropical climate). The annual average temperature and rainfall in Navirai is $22.4^{\circ} \mathrm{C}$ and $1517 \mathrm{~mm}$, respectively. The climatic data during the conduction of the experiment are summarized in Table 1.

\section{Experimental design}

The experimental design used was randomized blocks in a double factorial scheme $(6 \times 3)$, with four replications. The first factor was constituted by soil cover. The second factor was the sampling period (March/2015, October/2015 and June/2016). The experiment was implemented in a strip scheme to enable the operation of machinery. Each experimental plot measured $8.00 \times 10.50 \mathrm{~m}$, totaling $84 \mathrm{~m}^{2}$ per experimental unit.

\section{Field establishment and treatments}

In October 2014, a corrective was applied to the experimental plots, except for the conventional system, which was kept as fallow (F). The applied dose of corrective was calculated aiming to increase base saturation to $60 \%$. The application manually performed in a cover, using dolomitic filler limestone. Subsequently, the corrective was incorporated and the soil was prepared with plowing and two harrows, obtaining a good condition for mechanized sowing.

Sowing of cover and corn species was carried out in December 2014, with basic fertilization of $300 \mathrm{~kg} \mathrm{ha}^{-1}$ of the formula 08-28-16 for all treatments, detailed below:
Millet (MI): spacing of $0.45 \mathrm{~m}$, sowing depth of $3 \mathrm{~cm}$ and use of $8 \mathrm{~kg} \mathrm{ha}^{-1}$ of seeds of the BRS 1501 variety;

Forage sorghum (FS): spacing of $0.45 \mathrm{~m}$ between rows, sowing depth of $3 \mathrm{~cm}$, with a quantity of seeds of $10 \mathrm{~kg} \mathrm{ha}^{-1}$. The cultivar IAC - Santa Elisa was used;

Crotalaria ochroleuca $(\mathrm{Cr})$ : spacing between rows of $0.45 \mathrm{~m}$ and sowing depth of $3 \mathrm{~cm}$, using $8 \mathrm{~kg} \mathrm{ha}^{-1}$ of seeds;

Urochloa ruziziensis (brachiaria) (Ur): spacing between rows of $0.45 \mathrm{~m}$ and sowing depth of $2 \mathrm{~cm}$, using $4 \mathrm{~kg} \mathrm{ha}^{-1}$ of pure viable seeds;

Corn + Urochloa ruziziensis (Co + Ur): For the corn + brachiaria consortium, the corn hybrid DKB 390 was used. The corn was sown with spacing between rows of $0.90 \mathrm{~m}$, with the forage implanted between the rows (interim row method). For corn, the sowing density of 5 plants $\mathrm{m}^{-1}$ was used. For the forage, the population of 10 plants $\mathrm{m}^{-2}$ was adopted. In addition to the basic fertilization, $50 \mathrm{~kg} \mathrm{ha}^{-1}$ of nitrogen and potassium were applied via protected urea and potassium chloride, respectively, when the plants were in the four-leaf stage developed in all treatments.

The mechanical handling of all cover species was carried out with a rotary shredder, about 130 days after sowing. To determine the dry phytomass produced by cover crops and corn, three subsamples of $1.8 \mathrm{~m}$ were collected. It made up a sample composed of the plants contained in $5.4 \mathrm{~m}^{2}$, except for the Urochloa ruziziensis treatment, for which three were samples of $0.68 \mathrm{~m}$ sub-collected, making up a $2.04 \mathrm{~m}^{2}$ subsample. The degraded fallow pasture also had the production of phytomass before the planting of cassava. These aliquots were dehydrated in a forced aeration oven at $60^{\circ} \mathrm{C}$, for 72 hours, with subsequent weighing. Subsequently, the data obtained were converted to $\mathrm{kg} \mathrm{ha}^{-1}$.

The cassava cultivar 'Baianinha' was planted in May 2015, on the straw of the ground cover under evaluation. The conventional system treatment associated with degraded pasture $(P)$, which was planted after mechanical soil preparation. Planting was done mechanically with a two-row planter. Sowing was done in simple rows, with spacing and $1.00 \mathrm{~m}$ between rows and $0.70 \mathrm{~m}$ between plants, with a population of 14,286 plants ha ${ }^{-1}$. Each plot consisted of eight planting lines with 15 plants in each line. The sample collection area for analysis was the plants of the three central lines, except for the plants at the end of the line. The planting depth was $0.10 \mathrm{~m}$. Fertilization of planting, was formulated as $04-20-20+\mathrm{Zn}$ at a dose of $160 \mathrm{~kg} \mathrm{ha}^{-1}$. 


\section{Parameters evaluated}

The evaluations of the edaphic invertebrate macrofauna were carried out in three periods. The first in March 2015, 100 days after the sowing of cover plants. The second in October 2015, 165 days after the cassava planting and the third in June 2016, 13 months after the cassava implantation. In each system, four blocks of $0.25 \mathrm{~m} \times 0.25 \mathrm{~m}$ $x 0.20 \mathrm{~m}$ were sampled randomly, following the TSBF Tropical Soil Biology and Fertility collection method (Anderson and Ingram, 1993). 72 soil samples were manually selected and the organisms found (>10 $\mathrm{mm}$ long and/or $>2$ $\mathrm{mm}$ body diameter) extracted and stored in a $70 \%$ ethanol solution. In the laboratory, the organisms were identified and counted. The fauna components were identified at the level of class, order or family.

The characterization of the macrofauna community was carried out based on the taxonomic composition (\%); abundance (number of trap individuals ${ }^{-1}$ ); wealth (number of groups); Shannon's diversity index, obtained by the relation: $\left(\mathrm{H}^{\prime}=-\sum \mathrm{pi} 1 \mathrm{npi}\right)$, where: $\mathrm{pi}=\mathrm{ni} / \mathrm{N} ; \mathrm{ni}=$ abundance of each group and $\mathrm{N}=$ total number of groups (Shannon and Weaver, 1949); Pielou's equitability index $(e=H / \log S$, where $\mathrm{H}=$ Shannon's index and $\mathrm{S}=$ total number of groups in the community) (Pielou, 1977) and Simpson's dominance index $\left(\mathrm{S}=\sum(\mathrm{ni} / \mathrm{N})^{2}\right.$, where: $\mathrm{ni}=$ number of individuals in the group $\mathrm{i}$ and $\mathrm{N}=$ sum of the density of all groups). In addition, the classes, orders or family found were brought together into functional groups according to the main eating habits they develop in the environment (Moço et al., 2005).

\section{Statistical analysis}

The data obtained were submitted to normality and homogeneity tests of variance and were transformed to meet the assumptions of ANOVA, when necessary. Then, they were subjected to analysis of variance and the means compared by the Tukey test, at $5 \%$ significance, except for the frequency and relative density of soil organisms. In addition, the data on abundance, wealth, diversity, equitability and dominance (average of the three evaluation periods) were submitted to multivariate cluster analysis, adopting the method of the most distant neighbor (complete linkage), to describe the dissimilarity between the systems. The data were grouped using the Joining method, using Euclidean distances (Statistica, 1997).

\section{Conclusions}

The use of cover crops in the pre-cultivation of cassava in the no-tillage system provided favorable conditions for the populations of the soil invertebrate macrofauna, with greater emphasis on the groups Isoptera and Formicidae. The use of cover crops stimulated the activity of macrofauna individuals belonging to the predatory and saprophagouspredator functional groups, increasing their populations over time. Forage sorghum influenced Simpson's higher dominance index in relation to other soil coverings, regardless of the evaluation period. However, the other ecological index variables were not affected by the coverage. The abundance of organisms, richness of groups and diversity index were influenced by the sampling periods, showing the influence of the seasonality of the precipitation in the soil invertebrate macrofauna community.

\section{Acknowledgment}

The authors acknowledge the Brazilian Agricultural Research Company (EMBRAPA), EMBRAPA West Agricultural unit, for the use of the structure in the research developments.

\section{References}

Almeida MAX, Souto JS, Andrade AP (2015) Sazonalidade da macrofauna edáfica do Curimataú da Paraíba, Brasil. Ambiência. 11(2):393-407.

Alvarenga RC, Cabezas WAL, Cruz JC, Santana DP (2001) Plantas de cobertura de solo para sistema plantio direto. Informe Agropecuário. 22(208):25-36.

Amabile RF, Correia JR, Freitas PL, Blancaneaux P, Gamaliel J (1994) Efeito do manejo de adubos verdes na produção de mandioca (Manihot esculenta Crantz). Pesq Agropecu Bras. 29(8):1193-1199.

Anderson JM, Benjamin DH, Müller W, Griffeths AD (2002) Using ants as bioindicators in land management simplifying assessment of ant community responses. J Appl Ecol. 39(1):8-17.

Anderson JM, Ingram JSI (eds) (1993) Tropical soil biology and fertility: a handbook of methods, 2 rd edn. Oxford University Press, Wallingford. 240.

Aquino AM, Silva RF, Mercante FM, Correia MEF, Guimarães MF, Lavelle P (2008) Invertebrate soil macrofauna under different ground cover plants in the no-till system in the Cerrado. Eur J Soil Biol. 44(2):191-197.

Baretta D, Santos JCP, Mafra AL, Wildner LP, Miquelluti DJ (2003) Fauna edáfica avaliada por armadilhas de catação manual afetada pelo manejo do solo na região oeste catarinense. R Ci Agrovet. 2(2):97-106

Brown GG (1995) How do earthworms affect microfloral and faunal community diversity? Plant Soil 170:209-231.

Carvalho WP, Carvalho GJ, Abbade Neto DO, Teixeira LGV (2013) Desempenho agronômico de plantas de cobertura usadas na proteção do solo no período de pousio. Pesq Agropecu Bras. 48(2):157-166.

Cordeiro FC, Dias FC, Merlim AO, Correia MEF, Aquino AM, Brown G (2004) Diversidade da macrofauna invertebrada do solo como indicadora da qualidade do solo em sistema de manejo orgânico de produção. Rev Univ Rural, Sér $\mathrm{Ci}$ Vida. 24(2):29-34.

Correia MEF, Oliveira LD (2005) Importância da fauna de solo para a ciclagem de nutrientes. In: Aquino AM, Assis RL (eds) Processos biológicos no sistema solo-planta: ferramentas para uma agricultura sustentável, $1 \mathrm{rd}$ edn. Embrapa Informação Tecnológica, Seropédica. 24.

Cragg RG, Bardgett R (2001) How changes in soil faunal diversity and composition within a trophic group influence decomposition processes. Soil Biol Biochem. 33(15):20732081.

Crotty FV, Fychan R, Scullion J, Sanderson R, Marley CL (2015) Assessing the impact of agricultural forage crops on soil biodiversity and abundance. Soil Biol Biochem. 91:119126.

Cunha HF, Morais PPAM (2010) Relação espécie-área em cupinzeiros de pastagem, Goiânia-GO, Brasil. Entomo Brasilis. 3(3):60-63. 
Devide ACP, Castro CM, Valle TL, Feltran JC, Almeida JCR (2017) Cultivo de mandioca de mesa em plantio direto e convencional sobre diferentes culturas de cobertura. Rev Bras Energ Renov. 6(2):274-285.

Dudás P, Menyhárt L, Gedeon C, Ambrus G, Tóth F (2016) The effect of hay mulching on soil temperature and the abundance and diversity of soil-dwelling arthropods in potato fields. Eur J Entomol. 113:456-461.

González G, Ley RE, Schmidt SK, Zou X, Seastedt TR (2001) Soil ecological interactions: comparisons between tropical and subalpine forests. Oecologia. 128:549-556.

Guimarães NF, Fontanetti A, Fujihara RT, Gallo AS, Souza MDB, Morinigo KPG, Silva RF (2016) Fauna invertebrada epigéica associada a diferentes sistemas de cultivo do cafeeiro. Coffee Sci. 11(4):484-494.

Instituto Brasileiro de Geografia e Estatística (2017) Indicadores IBGE: Estatística da produção agrícola.

Köppen W, Geiger R (1928) Klimate der Erde. Gotha: Verlag Justus Perthes. Wall-map $150 \times 200 \mathrm{~cm}$.

Lavelle P, Spain AV (eds) (2001) Soil ecology. 1 rd edn. Kluwer Academic, Dordrecht. 654.

Machado DL, Pereira MG, Correira MEF, Diniz AR, Menezes CEG (2015) Fauna edáfica na dinâmica sucessional da mata atlântica em floresta estacional semidecidual na bacia do rio Paraíba do Sul - RJ. Cienc Florest. 25(1):91-106.

Marasas M, Sarandón S, Cicchino A (2010) Semi-natural habitats and field margins in a typical agroecosystem of the Argentinean pampas as a reservoir of carabid beetles. J Sustain Agric Sci. 34(2):153-168.

Marques DM, Silva AB, Silva LM, Moreira EA, Pinto GS (2014) Macrofauna edáfica em diferentes coberturas vegetais. Biosc J. 30(5):1588-1597.

Moço MKS, Gama-Rodrigues EF, Gama-Rodrigues AC, Correia MEF (2005) Caracterização da fauna edáfica em diferentes coberturas vegetais na região Norte Fluminense. $\mathrm{R}$ Bras $\mathrm{Ci}$ Solo. 29(4):555-564.

Neutel AM, Heesterbeek JAP, De Ruiter PC (2002) Stability in real food webs: weak links in long loops. Science. 296(5570):1120-1123.
Oliveira JOAP, Vidigal Filho OS, Tormena CA, Pequena MG, Scapim CA, Muniz AS, Sagrilo E (2001) Influência de sistemas de preparo do solo na produtividade da mandioca. R Bras Ci Solo. 25(2):443-450.

Pielou EC (1977) Mathematical Ecology. Wiley, New York. 385.

Rousseau GX, Dehevels O, Arias IR, Somarriba E (2012) Indicating soil quality in cacao-based agroforestry systems and old-growth forests: The potential of soil macrofauna assemblage. Ecol Indic. 23:535-543.

Santos GG, Silveira PM, Marchão RL, Becquer T, Balbino LC (2008) Macrofauna edáfica associada a plantas de cobertura em plantio direto em um Latossolo Vermelho do Cerrado. Pesq Agropecu Bras. 43(1):115-122.

Santos SRQ, Vitorino MI, Harada AY, Souza AML, Souza EB (2012) A riqueza das formigas relacionada aos períodos sazonais em Caxiuanã durante os anos de 2006 e 2007. Rev Bras de Meteorol. 27(3):307-314.

Sayer EJ, Sutcliffe LME, Ross RIC, Tanner EVJ (2010) Arthropod abundance and diversity in a lowland tropical forest floor in Panama: The role of habitat space vs. nutrient concentrations. Biotropica. 42(2):194-200.

Shannon CE, Weaver W (1949) The mathematical theory of communication. $1 \mathrm{rd}$ edn. University of Illinois, Urbana.144.

Silva RF, Borges DC, Garib DM, Mercante FM (2008) Atributos físicos e teor de matéria orgânica na camada superficial de um argissolo vermelho cultivado com mandioca sob diferentes manejos. $\mathrm{R}$ Bras $\mathrm{Ci}$ Solo. 32(6):2435-2441.

Silva RF, Tomazi M, Pezarico CR, Aquino AM, Mercante FM (2007) Macrofauna invertebrada edáfica em cultivo de mandioca sob sistemas de cobertura do solo. Pesq Agropecu Bras. 42(6):865-871.

Statistica (Statistica For Windows Release 4.5 Statsoft - Inc) (1993) Cluster Analyses, Joining (Tree Clostering). Single Linkage.

Terry IMF, González LC, Gallardo MF, Cairo NC, Acosta NR, Prado RM (2015) Macrofauna del suelo em cuatro fincas en conversión hacia la producción agroecológica em el Municipio Cruces, Cuba. Centro Agrícola. 42(1):43-52. 